\title{
The role of OPRM1 polymorphism in the etiology of alcoholism
}

\author{
Agnieszka Samochowiec ${ }^{1, A-F}$, Jerzy Samochowiec ${ }^{2, A-F}$, Justyna Pełka-Wysiecka ${ }^{2, B}$, Jolanta Kucharska-Mazur 2,B, \\ Elżbieta Grochans ${ }^{3, C}$, Marcin Jabłoński' ${ }^{2, B}$, Przemysław Bieńkowski ${ }^{4, C}$, Sławomir Murawiec ${ }^{5, C}$, Iwona Małecka ${ }^{2, B}$, \\ Monika Mak ${ }^{2, C}$, Łukasz Kołodzieje ${ }^{6, B, C}$, Janusz Heitzman ${ }^{7, E}$, Anna Grzywacz ${ }^{2, A-E}$ \\ ${ }^{1}$ Department of Clinical Psychology, Institute of Psychology, University of Szczecin, Poland \\ ${ }^{2}$ Department of Psychiatry, Faculty of Medicine, Pomeranian Medical University in Szczecin, Poland \\ ${ }^{3}$ Department of Nursing, Faculty of Health Sciences, Pomeranian Medical University in Szczecin, Poland \\ ${ }^{4}$ Department of Psychiatry, Faculty of Health Sciences, Medical University of Warsaw, Poland \\ ${ }^{5}$ DIALOG Therapy Center, Warszawa, Poland \\ ${ }^{6}$ Department of Orthopedics, Faculty of Medicine, Pomeranian Medical University in Szczecin, Poland \\ ${ }^{7}$ Department of Forensic Psychiatry, Institute of Psychiatry and Neurology, Warszawa, Poland \\ A - research concept and design; B - collection and/or assembly of data; $\mathrm{C}$ - data analysis and interpretation; \\ $D$ - writing the article; $E$ - critical revision of the article; $F$ - final approval of the article
}

Address for correspondence

Jerzy Samochowiec

E-mail:samoj@pum.edu.pl

Funding sources

None declared

Conflict of interest

None declared

Received on February 5, 2017

Reviewed on March 7, 2017

Accepted on 0ctober 13, 2017

Published online on August 7, 2018

Cite as

Samochowiec A, Samochowiec J, Pełka-Wysiecka J, et al.

The role of OPRM1 polymorphism in the etiology of alcoholism. Adv Clin Exp Med. 2019;28(2):199-202. doi:10.17219/acem/78592

DOI

10.17219/acem/78592

Copyright

Copyright by Author(s)

This is an article distributed under the terms of the

Creative Commons Attribution Non-Commercial License

(http://creativecommons.org/licenses/by-nc-nd/4.0/)

\section{Abstract}

Background. Numerous studies have investigated the association between the OPRM1 A118G polymorphism (rs1799971) and alcohol dependence, but the results have been inconsistent. The endogenous opioid system has been implicated in the development of alcohol dependence for its prominent role in the central rewarding mechanism.

Objectives. The aim of this study was to evaluate the role of the A118G polymorphism of the OPRM1 gene in the pathogenesis of alcohol dependence syndrome (ADS).

Material and methods. The OPRM1 (rs1799971) polymorphism was investigated in an association study of a group of ADS patients ( $n=177$ ) and in subgroups (delirium tremens and/or seizures, age at onset $<26$ years, dissocial alcoholics, positive familial history of alcoholism, delirium tremens, and seizures). The control group consisted of healthy volunteers, with matched gender and age, and with psychiatric disorders excluded ( $n=162)$.

Results. Our research shows that there are differences in the genotypes and alleles of the OPRM1 polymorphism in the case-control study. Furthermore, we observed associations in our homogeneous subgroups - in the group of patients with ADS and accompanying delirium tremens and/or seizures at the genotype level, as well as in the subgroup of patients under 26 years of age with an early onset of dependence.

Conclusions. It is strongly possible that the $\mathrm{G}$ allele described in numerous studies can be associated with a response to treatment, but not typology, or the very predisposition toward alcoholism. It is necessary to carry out further research which would embrace a larger group of patients; it should be divided into other homogeneous subgroups, including, e.g., naltrexone pharmacotherapy.

Key words: alcohol dependence, OPRM1 gene, opioid system 


\section{Introduction}

The history of research on the opioid system dates back to the period of interest in the physiological effects of morphine, which is one of the alkaloids found in poppy seeds, or more precisely, opium. Thanks to the experiments carried out 38 years ago, morphine-binding receptors have been discovered. ${ }^{1,2}$ As part of the research, 3 basic types of opioid receptors $-\mu, \delta, \mathrm{\kappa}(\mathrm{mi}$, delta and kappa) - were singled out. Opioid receptors are mainly present in the central nervous system, in the cellular membrane of neurons. They can also be found in some types of smooth muscles, as well as the digestive tract, immune system cells, uterus, heart, and lungs.

The abovementioned receptors are essential for signal cascades, which are responsible for the feeling of pain, the regulation of motor and psychophysical functions, and mood control. Numerous studies have indicated the modulatory effects of opioid receptors on the frequency and intensity of drinking relapse. ${ }^{3,4}$ In medical circles, these findings have aroused hopes for the development of effective therapies for addiction, tailored to the needs of individual patients.

Research results have also proven that endogenous opioid peptides play a role in alcohol-related mechanisms. A single dose of alcohol promotes the secretion of $\beta$-endorphins and enkephalins, which stimulate opioid receptors. A lower level of $\beta$-endorphins may be a direct consequence of chronic alcohol abuse. ${ }^{5}$

It has also been proven that alcohol stimulates opioid peptide secretion and activates the reward system in the brain, thereby developing alcohol dependence. Accordingly, drugs which affect the opioid system may influence many behaviors associated with getting and consuming natural rewards (water, food or sex) and chemical rewards (alcohol, opiates or nicotine).

The $\mu$-opioid receptor (OPRM1) has been repeatedly investigated with special attention paid to its relationship with alcohol dependence syndrome (ADS), addiction to psychoactive substances, schizophrenia, obesity, Alzheimer's disease, palliative treatment, and sensitivity to pain. Many authors have indicated serious and numerous relationships between the effects of opioids and alcohol. ${ }^{6-11}$

In 2003, O'Brien's team conducted a study in which a response to naltrexone was associated with a specific genetic variant of the $\mu$-opioid receptor. ${ }^{12}$ The alcoholics with this genetic variant who were administered naltrexone were able to function without alcohol for a long time, had shorter periods of intensive drinking and could abstain from drinking (or drink very little), which made them less likely to relapse to addiction after their therapy. Individuals who respond to naltrexone show some similarities: a very strong craving for alcohol and a family history of alcoholism. They start drinking when they are young and have a so-called "strong head". On a biochemical level, their endorphin response is stronger than in those who do not respond to naltrexone. ${ }^{13}$

The aim of this study was to evaluate the role of the A118G polymorphism of the OPRM1 gene in the pathogenesis of ADS.

\section{Material and methods}

The OPRM1 (rs1799971) polymorphism (Fig. 1) was investigated in an association study of a group of ADS patients ( $\mathrm{n}=177$ ) and its subgroups (delirium tremens and/ or seizures, age at onset $<26$ years, dissocial alcoholics, positive familial history of alcoholism, delirium tremens, and seizures). The patients were screened for other psychiatric disorders. We used the Semi-Structured Assessment for the Genetics of Alcoholism (SSAGA) for patient phenotyping.

The control group consisted of healthy volunteers, with matched gender and age, and with psychiatric disorders excluded by using Primary Care Evaluation of Mental Disorders Patient Health Questionnaire (PRIME-MD) $(\mathrm{n}=162)$ (Table 1).

Table 1. Statistical characteristics of age in patients with ADS and in controls

\begin{tabular}{|l|c|c|c|c|}
\multicolumn{1}{|c|}{ Group } & $\mathrm{n}$ & $\begin{array}{c}\text { Mean } \\
\text { [years] }\end{array}$ & $\begin{array}{c}\text { SD } \\
\text { [years] }\end{array}$ & $\begin{array}{r}\text { Range } \\
\text { [years] }\end{array}$ \\
\hline ADS (men) & 177 & 33 & 8.8 & $20-61$ \\
\hline Controls (men) & 162 & 38 & 15.8 & $18-80$ \\
\hline
\end{tabular}

ADS - alcohol dependence syndrome; SD - standard deviation.

\section{Genotyping using a real-time polymerase chain reaction apparatus}

The genome DNA for the analysis was isolated from the leukocytes of circumferential blood using a salting method. Genotyping of the selected polymorphism in the OPRM1 gene was performed with the real-time polymerase chain reaction (PCR) method based on the use of fluorescent oligonucleotide probes, which hybridize with unique DNA sequences. The analysis of the OPRM1 gene polymorphisms was performed with a LightCycler 2.0 (Roche Diagnostics, Pleasanton, USA), using the melting curve analysis for specific alleles. Genotyping results after the completion of the reaction were analyzed using LightCycler software v. 4.1 (Roche Diagnostics).

\section{Statistical analysis}

Differences between the controls and the ADS subjects were tested with the $\chi^{2}$ test and were considered significant when type 1 error was $<5 \%$, using Statistical Package for Social Sciences (SPSS) v. 9.0 for Windows (Microsoft Corp., Armonk, USA). The Hardy-Weinberg equilibrium was calculated using SAS v. 8.02 for Windows (SAS Institute, Cary, USA). 


\section{Results}

We examined 162 alcohol-dependent patients vs 177 cases and found that there were differences in genotypes and alleles of the OPRM1 polymorphism. What is more, we observed associations in our homogeneous subgroups - in the group of patients with ADS and accompanying delirium tremens and/or seizures (Table 2) at the genotype level, as well as in the subgroup of patients under 26 years of age with an early onset of dependence (Table 2).

\section{Discussion}

In 2007, Van den Wildenberg et al. stated that heavydrinking individuals with a copy of the $G$ allele are more prone to experiencing cue-induced craving after exposure to an alcoholic beverage. ${ }^{14}$ Interestingly, carriers of at least 1 rs1799971(G) allele appear to have stronger cravings for alcohol than carriers of 2 rs1799971(A) alleles, and are thus hypothesized to be at a higher risk for alcoholism. On the basis of the abovementioned studies, we can conclude that these findings have several implications. Firstly, individuals with a copy of the G allele seem to be more sensitive to cueinduced subjective cravings for alcohol than individuals homozygous for the A allele. ${ }^{14}$ Another interesting aspect of the literature in this respect is a study performed by Anton et al., in which among over 200 alcoholics treated with naltrexone, rs1799971(G) carriers receiving the drug had a higher percentage of abstinent days and a lower percentage of heavy drinking days $(p=0.04)$ compared to those receiving a placebo, whereas rs1799971(A;A) homozygotes showed no differences connected with medication. Upon treatment with naltrexone, $87 \%$ of rs1799971(G) carriers had a good clinical outcome, compared to only $55 \%$ of individuals with the $(\mathrm{A} ; \mathrm{A})$ genotype. ${ }^{15}$

Although the association between a polymorphism of the OPRM1 receptor gene and adolescent alcohol misuse was tested by Ray et al., our findings provide the first evidence that the A118G single-nucleotide polymorphism (SNP) of the OPRM1 gene is associated with alcohol use disorder (AUD) diagnoses during adolescence, as well as with a greater number of alcohol-related problems among adolescent drinkers. ${ }^{4}$ Those who carried the G allele turned

Chr. 6

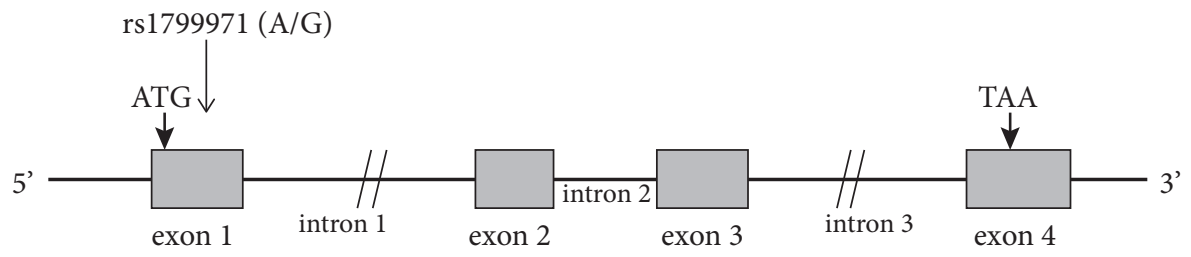

human $\mu$-opioid receptor gene OPRM1

Fig. 1. The $\mu$-opioid receptor gene (OPRM1) is located on chromosome 6, at [6q25.2]; it consists of 4 exons separated by introns

Table 2. Frequencies of genotypes and alleles of the investigated OPRM1 (rs1799971) polymorphism in alcoholics ( $\mathrm{n}=177$ ) and in the control group $(\mathrm{n}=162)$

\begin{tabular}{|c|c|c|c|c|c|c|c|c|}
\hline \multirow[b]{2}{*}{ Groups } & \multirow[b]{2}{*}{$\mathrm{n}$} & \multicolumn{3}{|c|}{ Genotypes } & \multirow[b]{2}{*}{$p$-value } & \multicolumn{2}{|c|}{ Alleles } & \multirow[b]{2}{*}{$p$-value } \\
\hline & & $\begin{array}{l}\mathrm{A} / \mathrm{A} \\
\mathrm{n}(\%)\end{array}$ & $\begin{array}{l}\mathrm{A} / \mathrm{G} \\
\mathrm{n}(\%)\end{array}$ & $\begin{array}{l}\mathrm{G} / \mathrm{G} \\
\mathrm{n}(\%)\end{array}$ & & $\begin{array}{c}A \\
n(\%)\end{array}$ & $\begin{array}{c}\mathrm{G} \\
\mathrm{n}(\%)\end{array}$ & \\
\hline Controls & 162 & $\begin{array}{c}119 \\
(0.73)\end{array}$ & $\begin{array}{c}40 \\
(0.25)\end{array}$ & $\begin{array}{c}3 \\
(0.02)\end{array}$ & - & $\begin{array}{c}278 \\
(0.86)\end{array}$ & $\begin{array}{c}46 \\
(0.14)\end{array}$ & - \\
\hline Cases & 177 & $\begin{array}{c}146 \\
(0.82)\end{array}$ & $\begin{array}{c}29 \\
(0.16)\end{array}$ & $\begin{array}{c}2 \\
(0.02)\end{array}$ & 0.13 & $\begin{array}{l}321 \\
(0.91)\end{array}$ & $\begin{array}{c}33 \\
(0.09)\end{array}$ & $0.048^{*}$ \\
\hline Delirium tremens and/or seizures & 51 & $\begin{array}{c}45 \\
(0.88)\end{array}$ & $\begin{array}{c}4 \\
(0.08)\end{array}$ & $\begin{array}{c}2 \\
(0.04)\end{array}$ & $0.02^{*}$ & $\begin{array}{c}94 \\
(0.92)\end{array}$ & $\begin{array}{c}8 \\
(0.08)\end{array}$ & 0.09 \\
\hline $\mathrm{AOO}<26$ & 122 & $\begin{array}{c}104 \\
(0.85)\end{array}$ & $\begin{array}{c}18 \\
(0.15)\end{array}$ & $\begin{array}{c}0 \\
(0.0)\end{array}$ & $0.03^{*}$ & $\begin{array}{l}226 \\
(0.93)\end{array}$ & $\begin{array}{c}18 \\
(0.07)\end{array}$ & $0.01^{*}$ \\
\hline Dissocial alcoholics & 63 & $\begin{array}{c}52 \\
(0.82)\end{array}$ & $\begin{array}{c}10 \\
(0.16)\end{array}$ & $\begin{array}{c}1 \\
(0.02)\end{array}$ & 0.35 & $\begin{array}{l}114 \\
(0.9)\end{array}$ & $\begin{array}{c}12 \\
(0.01)\end{array}$ & 0.18 \\
\hline $\begin{array}{l}\text { Positive familial history } \\
\text { of alcoholism }\end{array}$ & 56 & $\begin{array}{c}47 \\
(0.84)\end{array}$ & $\begin{array}{c}8 \\
(0.16)\end{array}$ & $\begin{array}{c}0 \\
(0.0)\end{array}$ & 0.22 & $\begin{array}{c}103 \\
(0.92)\end{array}$ & $\begin{array}{c}9 \\
(0.08)\end{array}$ & 0.09 \\
\hline Delirium tremens & 32 & $\begin{array}{c}27 \\
(0.84)\end{array}$ & $\begin{array}{c}3 \\
(0.1)\end{array}$ & $\begin{array}{c}2 \\
(0.06)\end{array}$ & 0.07 & $\begin{array}{c}57 \\
(0.89)\end{array}$ & $\begin{array}{c}7 \\
(0.11)\end{array}$ & 0.48 \\
\hline Seizures & 31 & $\begin{array}{c}27 \\
(0.87) \\
\end{array}$ & $\begin{array}{c}3 \\
(0.1) \\
\end{array}$ & $\begin{array}{c}1 \\
(0.03)\end{array}$ & 0.17 & $\begin{array}{c}57 \\
(0.92)\end{array}$ & $\begin{array}{c}5 \\
(0.08)\end{array}$ & 0.19 \\
\hline
\end{tabular}

AOO $<26$ - age of onset less than 26 years; $p$-values of the $x^{2}$ test for genotypes; ${ }^{*}$ statistical significance. 
to drinking to enhance the positive affect more strongly than those who were homozygous for the A allele, and drinking to enhance the positive affect mediated the association between OPRM1 and alcohol-related problems. ${ }^{16}$

The meta-analysis performed by Chen et al. in 2012 shows a list of 12 independent studies with 1,900 cases and 2,382 controls - 5 studies were conducted in Asians and 7 in Caucasians. Ethnicity-specific meta-analyses revealed that the A118G polymorphism significantly correlated with the risk for alcohol dependence in Asians, but not in Caucasians. ${ }^{17}$ However, in central Sweden - according to Bart et al. - the functional variant $118 \mathrm{G}$ allele in exon 1 of OPRM1 was associated with an increased attributable risk of alcohol dependence. ${ }^{18}$

Numerous researchers have associated the OPRM1 gene and its polymorphic variant with a response to naltrexone. In the study performed by Bart et al., the results indicate that individuals with at least 1 copy of the $G$ allele reported a lower alcohol craving and a stronger alcohol-induced "high" across rising breath alcohol concentrations. ${ }^{18} \mathrm{Nal}-$ trexone was found to blunt the effects of alcohol on stimulation, positive mood, craving, and enjoyment. The effects of naltrexone on blunting the alcohol-induced "high" were stronger among individuals with the G allele. ${ }^{4}$

Rommelspacher et al. found little evidence in relation to these associations and concluded that there was no significant difference in the frequency of the Asp40 allele between the control subjects and the alcohol-dependent subjects with a family history of parental alcoholism, subjects with early-onset alcohol dependence or alcohol-dependent subjects with severe withdrawal symptoms. Their results provide only some evidence for an allelic association of the Asn40Asp SNP with alcohol dependence. ${ }^{19}$

\section{Conclusions}

In light of the abovedescribed findings we can say the results are unambiguous - we observed a frequent occurrence of the A allele in the control group and in selected homogeneous subgroups.

It is strongly possible that the $\mathrm{G}$ allele described in numerous studies can be associated with a response to treatment, but not with typology or the very predisposition toward alcoholism. It is necessary to carry out further research which would embrace a larger group of patients; it should be divided into other homogeneous subgroups, including, e.g., how the patients respond to naltrexone pharmacotherapy. ${ }^{20}$

\section{References}

1. Hughes J. Isolation of an endogenous compound from the brain with pharmacological properties similar to morphine. Brain Res. 1975; 88(2):295-308.

2. Terenius $L$, Wahlström $A$. Search for an endogenous ligand for the opiate receptor. Acta Physiol Scand. 1975;94(1):74-81.

3. Latt NC, Jurd S, Houseman J, Wutzke SE. Naltrexone in alcohol dependence: A randomised controlled trial of effectiveness in a standard clinical setting. Med J Aust. 2002;176(11):530-534.

4. Ray LA, Hutchison KE. Effects of naltrexone on alcohol sensitivity and genetic moderators of medication response. Arch Gen Psychiatry. 2007;64(9):1069-1077.

5. Kiefer F, Horntrich M, Jahn H, Wiedemann K. Is withdrawal-induced anxiety in alcoholism based on $\beta$-endorphin deficiency? Psychopharmacology (Berl). 2002;162(4):433-437.

6. Agabio R, Colombo G. GABAB receptor as therapeutic target for drug addiction: From baclofen to positive allosteric modulators [in Polish]. Psychiatr Pol. 2015;49(2):215-223.

7. Iwanicka KA, Olajossy M. The concept of alcohol craving [in Polish]. Psychiatr Pol. 2015;49(2):295-304.

8. Oswald LM, Wand GS. Opioids and alcoholism. Physiol Behav. 2004; 81(2):339-358.

9. Kiejna A, Piotrowski P, Adamowski T, et al. The prevalence of common mental disorders in the population of adult Poles by sex and age structure - an EZOP Poland study [in Polish]. Psychiatr Pol. 2015;49(1): 15-27.

10. Klimkiewicz A, Klimkiewicz J, Jakubczyk A, Kieres-Salomoński I, Wojnar M. Comorbidity of alcohol dependence with other psychiatric disorders. Part I. Epidemiology of dual diagnosis [in Polish]. Psychiatr Pol. 2015;49(2):265-275.

11. Klimkiewicz A, Klimkiewicz J, Jakubczyk A, Kieres-Salomoński I, Wojnar M. Comorbidity of alcohol dependence with other psychiatric disorders. Part II. Pathogenesis and treatment [in Polish]. Psychiatr Pol. 2015;49(2):277-294.

12. O'Brien CP. Research advances in the understanding and treatment of addiction. Am J Addict. 2003;12(Suppl 2):S36-47.

13. Anton RF, Oroszi G, O'Malley $\mathrm{S}$, et al. An evaluation of mu-opioid receptor (OPRM1) as a predictor of naltrexone response in the treatment of alcohol dependence. Arch Gen Psychiatry. 2008;65(2): 135-144.

14. Van den Wildenberg E, Wiers RW, Dessers J, et al. A functional polymorphism of the mu-opioid receptor gene (OPRM1) influences cue-induced craving for alcohol in male heavy drinkers. Alcohol Clin Exp Res. 2007;1:1-10.

15. Anton R, Oroszi G, O'Malley S, Couper D, Swift R. An evaluation of $\mu$-opioid receptor (OPRM1) as a predictor of naltrexone response in the treatment of alcohol dependence. Arch Gen Psychiatry. 2008;65(2): 135-144.

16. Miranda R, Ray L, Justus A, et al. Initial evidence of an association between OPRM1 and adolescent alcohol misuse. Alcohol Clin Exp Res. 2010;34:112-122.

17. Chen D, Liu L, Xiao Y, Peng Y, Yang C, Wang Z. Ethnic-specific metaanalyses of association between the OPRM1 A118G polymorphism and alcohol dependence among Asians and Caucasians. Drug Alcohol Depend. 2012;123(1-3):1-6.

18. Bart G, Kreek MJ, Ott J, et al. Increased attributable risk related to a functional mu-opioid receptor gene polymorphism in association with alcohol dependence in central Sweden. Neuropsychopharmacology. 2005;30(2):417-422.

19. Rommelspacher H, Smolka, M, Samochowiec J, Hoehe MR. Genetic analysis of the $\mathrm{m}$-opioid receptor in alcohol-dependent individuals. Alcohol. 2001;24(2):129-135.

20. Bieńkowski P. Pharmacological features of naltrexone and its use in the treatment of alcohol dependence [in Polish]. Psychiatr Pol. 2013;47(1):117-126. 